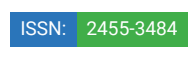

\section{Cannabis and Endocannabinoid System}

\author{
Somchai Amornyotin* \\ Department of Anesthesiology and Siriraj GI Endoscopy Center, Faculty of Medicine Siriraj Hospital, \\ Mahidol University, Bangkok, Thailand
}

Received: 28 December, 2020

Accepted: 18 January, 2021

Published: 19 January, 2021

*Corresponding author: Somchai Amornyotin, Associate Professor, Department of Anesthesiology and Siriraj GI Endoscopy Center, Faculty of Medicine Siriraj Hospital, Mahidol University, Bangkok 10700, Thailand, Tel: 66-2-419-7990; Fax: 662-4113256; E-mail: somchai. amo@mahidol.ac.th; amornyotin.somchai@gmail.com ORCID: https://orcid.org/0000-0002-4345-5836

Keywords: Cannabis; Endocannabinoid system; Cannabinoid; Marijuana

https://www.peertechz.com

Check for updates

\title{
Abstract
}

The endocannabinoid system is involved in various physiological pathways in the human body. A large number of endogenous cannabinoids have been acknowledged, and cannabinoid receptor type 1 (CB-1) and cannabinoid receptor type 2 (CB-2) have been categorized. The activation of endocannabinoid system could regulate the activity in several neural pathways. The complex functions of this system have generated multiple new targets for pharmacotherapies. Several research studies have concentrated on these issues. However, these efforts have been generally unsuccessful. Although cannabinoids have therapeutic potential, their psychoactive properties have largely limited their usage in clinical practice. In this review, the author briefly summarized the knowledge of cannabis and the endocannabinoid system.

\section{Introduction}

In 1964, Raphael Mechoulam and colleagues at Hebrew University in Jerusalem isolated Tetrahydrocannabinol (THC) and found it to be the main psychoactive compound in cannabis. In 1988, Allyn Howlett and co-workers at St. Louis University discovered the cannabinoid receptor. Anandamide (N-arachidonoylethanolamine, AEA) was the first cannabislike compound was discovered in 1992. The second compound, 2-Arachidonolygylycerol (2-AG), was detected in 1995. These compounds were named "endogenous cannabinoids or endocannabinoids". Endogenous cannabinoids are endogenous lipids that employ the cannabinoid receptors. An important feature of these endocannabinoids is that their precursors are presented in lipid membranes. Despite anandamide and 2-AG both containing arachidonic acid, their routes of synthesis and degradation are almost completely different and are facilitated by different enzymes [1]. These endocannabinoids are implicated in different physiological and pathological functions [2,3]. Cannabinoids produce their effects through the activation of distinct $G$ protein-coupled receptors identified as the Cannabinoid receptor type 1 (CB-1) $[4,5]$ and Cannabinoid receptor type 2 (CB-2) [6]. Although AEA and 2-AG have significant differences in receptor selectivity, both endocannabinoids are generated on demand [7-9].
The human body has a cannabis chemical producing factory called the endocannabinoid system. All vertebrate species, including humans, have an endocannabinoid system. The endocannabinoid system is one of the great unknowns of the biology. Fundamentally, it is a neurotransmission system. This endocannabinoid system is contained of endogenous cannabinoids (endocannabinoids), cannabinoid receptors, and the enzymes responsible for the synthesis and degradation of endocannabinoid. It regulates the flow of signals that are being sent between cells for maintaining the balance. Endocannabinoids have a short life span. They are prepared and released on demand as a response to a trigger. The triggers include illness, injury, inflammation and other imbalances. This system regulates several physiologic pathways in the human body such as cardiovascular activity, pain perception, gastrointestinal activity, hormonal regulation, immune function and inflammation reactions.

The two types of cannabinoid receptors are type 1 receptor (CB1) and type 2 receptor (CB2). Both CB1 and CB2 cannabinoid receptors are $\mathrm{G}$ protein-coupled receptors [10]. The location of the two types of cannabinoid receptors has been mapped and described the various effects of cannabis. The $\mathrm{CB} 1$ receptors are commonly located in central nervous system that are related to the sensation of pain, emotion, motor control, memory, 
appetite, nausea and vomiting as well as pleasure and reward [11]. In addition, the $\mathrm{CB} 2$ receptors are usually located in the areas of body that are related to the immune system, peripheral nervous system and bone. However, some areas of the body such as heart, gastrointestinal system, liver, reproductive system and skin, express both type 1 and 2 receptors.

Endogenous cannabinoids occur naturally within the body. In contrast, exogenous cannabinoids are produced externally and seem to be capable of initiating the endocannabinoid system to a greater extent. The exogenous cannabinoids that are commonly found in cannabis are called phytocannabinoids. The phytocannabinoids can be found in hundreds of different plant species, they are present in the highest concentration in the cannabis plant. The cannabis plant is a natural medicine that could assist the balance of endocannabinoid system. However, there are actually 85 cannabinoids in the cannabis plant, along with hundreds of other compounds. Many of the compounds together creates a synergistic effect when all are present.

The endocannabinoid system can become underactive or overactive, which causes the body to malfunction and come out of a homeostatic state. When our endocannabinoid system is not working properly, we might have an imbalance, which can produce chronic medical conditions including epilepsy, autoimmune disease, myofascial pain, migraine, irritable bowel syndrome, complex regional pain syndrome, anxiety and depression, multiple sclerosis and parkinson's disease. Importantly, overactivity or underactivity of the endocannabinoid system has been associated with some disease states. Overactivity of this system might be correlated with obesity and type II diabetes. Previous reports demonstrated that obese people and type II diabetic patients had abnormally increased blood levels of endocannabinoids. Moreover, underactivity of the endocannabinoid system would decrease the ability to maintain homeostasis. The three most clinical endocannabinoid deficiency are migraines, fibromyalgia, and irritable bowel syndrome. All of these are associated with a higher incidence of anxiety and/or depression [12]. The number of cannabinoid receptors could change in response. Intensification in the number of cannabinoid receptors are associated with some disease states such as autistic children and depression persons who committed suicide. Diminution in the number of cannabinoid receptors are related to chronic heavy users of THC-rich cannabis.

Phytocannabinoids are cannabinoids found in plants that stimulate these same receptors. The most famous of these are THC (delta-9-tetrahydrocannabinol) and CBD (or cannabidiol). Cannabis is an herb which has a diverse range of cannabinoids and terpenes present. Cannabinoids in Cannabis are extremely alike to those present and naturally produced by the human body. The medical use of cannabis is now legal in several countries, including Canada and most of Europe and the United States. If the cannabinoids and their analogs become therapeutic agents, they are beneficial for the treatment of chronic conditions. The possibility of accumulative toxicity must be considered. The long-term toxicity of cannabinoids in humans remains principally unknown. The regular use of cannabis tends to happen in people who have experience with other legal and illegal recreation drugs. Heavier cannabis users will more likely be alcohol users and tobacco smokers.

Several animal studies had been investigated the toxic effects of cannabis on brain and other organs of the body. These studies demonstrated little evidence of brain and other organs damage. To date, there are no fatal overdoses of cannabis because the area of brain responsible for breathing and heart rate does not have cannabinoid receptors. A previous study evaluated and compared the long term effects of the cannabis use in 63 current heavy cannabis users and 72 control subjects. The study showed that there were not significantly different between the two groups [13]. Some reports presented the correlation of the use of THC and the possible development of abnormal cardiac rhythms [14-16]. However, a recent review of the risks of cardiovascular disease confirmed that marijuana use was not significantly correlated with an increased risk of cardiovascular disease [17].

In recent years, a rapid increase in the medical and recreational use of cannabis. Several products and chemical compounds derived from different species of the cannabis plant. Cannabis based products for medicinal use comprise cannabinoids derived from the cannabis plant, including $\Delta$ 9-tetrahydrocannabinol (THC), cannabidiol (CBD), or a combination of THC and CBD. THC is the fundamental of cannabis that could create the psychotic effect, whereas CBD is not hallucinogenic at a typical dose. THC provides a higher risk of adverse events compared with CBD. To date, nonmedicinal CBD products are lawful and extensively available on the internet and from health food venders, but they lack quality standards and should not be used for medicinal purposes [18].

Despite increased cannabis use and a changing state-level policy landscape, certain evidence regarding the short and long-term health effects of cannabis use continues indefinable. Unlike alcohol or tobacco, no established standards exist to help guide individuals as they make choices how to use cannabis safely. For therapeutic uses, a systematic review and meta-analysis demonstrated that there was moderatevalue confirmation to support the use of cannabinoids for the management of chronic pain and spasticity. There was low-value confirmation suggesting that cannabinoids were related with improvements in nausea and vomiting owing to chemotherapy, weight gain in HIV infection, sleep disorders, and Tourette syndrome. Cannabinoids were associated with an increased risk of short-term adverse events [19]. Importantly, a broad set of evidence-based research conclusions on the health effects of cannabis and cannabinoids need to be confirmed.

\section{Conclusion}

An understanding of human cannabinoid pharmacokinetics is important for the enlargement and monitoring of new therapeutic medications. The extensive manifestation and multipurpose functions of endocannbinoid system not only support its promising potential as a drug target for various diseases, but also make the unwanted side effects almost unavoidable. The discovery of an endocannabinoid 
signaling system has released new opportunities for research into understanding the mechanisms of cannabis actions, the role of the endocannabinoid system in homeostasis, and the development of treatment approaches on the phytocannabinoids.

\section{References}

1. Pacher P, Batkai S, Kunos $G$ (2006) The endocannabinoid system as an emerging target of pharmacotherapy. Pharmacol Rev 58: 389-462. Link: https://bit.ly/38UPPaJ

2. Di Marzo V, De Petrocellis L (2006) Plant, synthetic, and endogenous cannabinoids in medicine. Ann Rev Med 57: 553-574. Link: https://bit.ly/35Ltt9J

3. Piomelli D (2005) The endocannabinoid system: a drug discovery perspective Curr Opin Investig Drugs 6: 672-679. Link: https://bit.ly/39JOjqX

4. Zou S, Kumar U (2018) Cannabinoid receptors and the endocannabinoid system: signaling and function in the central nervous system. Int J Mol Sci 19: 833. Link: https://bit.ly/38TLQLG

5. Matsuda LA, Lolait SJ, Brownstein MJ, Young AC, Bonner TI (1990) Structure of a cannabinoid receptor and functional expression of the cloned cDNA. Nature 346: 561-564. Link: https://bit.ly/3bNsutt

6. Munro S, Thomas KL, Abu-Shaar M (1993) Molecular characterization of a peripheral receptor for cannabinoids. Nature 365: 61-65. Link: https://bit. ly/3qwqmKM

7. Kano M, Ohno-Shosaku T, Hashimotodani $Y$, Uchigashima $M$, Watanabe $M$ (2009) Endocannabinoid-mediated control of synaptic transmission. Physiol Rev 89: 309-380. Link: https://bit.ly/3nVMjB2

8. Castillo PE, Younts TJ, Chavez AE, Hashimotodani Y (2012) Endocannabinoid signaling and synaptic function. Neuron 76: 70-81. Link: https://bit.ly/391pLyB

9. Katona I, Freund TF (2008) Endocannabinoid signaling as a synaptic circuit breaker in neurological disease. Nat Med 14: 923-930. Link: https://bit. ly/3505sP6
10. Howlett AC, Barth F, Bonner TI, Cabral G, Casellas P, et al. (2002) International Union of Pharmacology. XXVII. Classification of cannabinoid receptors. Pharmacol Rev 54: 161-202. Link: https://bit.ly/3nVpNZh

11. Mackie K (2005) Distribution of cannabinoid receptors in the central and peripheral nervous system. Handb Exp Pharmacol 168: 299-325. Link: https://bit.ly/3p798mE

12. Russo EB (2016) Clinical endocannabinoid deficiency reconsidered: current research supports the theory in migraine, fibromyalgia, irritable bowel and other treatment-resistant syndromes. Cannabis Cannabinoid Res 1: 154-165. Link: https://bit.ly/2Kvo8vS

13. Pope HG, Gruber AJ, Hudson JI, Huestis MA, Yurgelun-Todd D (2001) Neuropsychological performance in long-term cannabis users. Arch Gen Psychiatry 58: 909-915. Link: https://bit.ly/2Ko9aHO

14. Fisher BA, Ghuran A, Vadamalai V, Antonios TF (2005) Cardiovascula complications induced by cannabis smoking: a case report and review of the literature. Emerg Med J 22: 679-680. Link: https://bit.ly/2XSNhDL

15. Kosior DA, Filipiak KJ, Stolarz P, Opolski G (2001) Paroxysmal atrial fibrillation following marijuana intoxication: a two-case report of possible association. Intern J Cardiol 78: 183-184. Link: https://bit.ly/2XNh5BC

16. Singh GK (2000) Atrial fibrillation associated with marijuana use. Pediatr Cardiol 21: 248. Link: https://bit.ly/3nTLHw2

17. Axiyan M, Adedinsewo D, Agasthi P, Onwuanyi A (2015) Cardiovascula disease among us adult marijuana users: national health and nutrition examination survey, 2011-2012. J Amer Coll Cardiol 65: A1425. Link: https://bit.ly/2XSd4vC

18. Freeman TP, Hindocha C, Green SF, Bloomfield MAP (2019) Medicinal use of cannabis based products and cannabinoids. BMJ 365: 11141. Link: https://bit.ly/39BXlq8

19. Whiting PF, Wolff RF, Deshpande S, Di Nisio M, Duffy S, et al. (2015) Cannabinoids for medical use-A systematic review and meta-analysis. JAMA 313: 2456-2473. Link: https://bit.ly/3qw3cnS

\section{Discover a bigger Impact and Visibility of your article publication with} Peertechz Publications

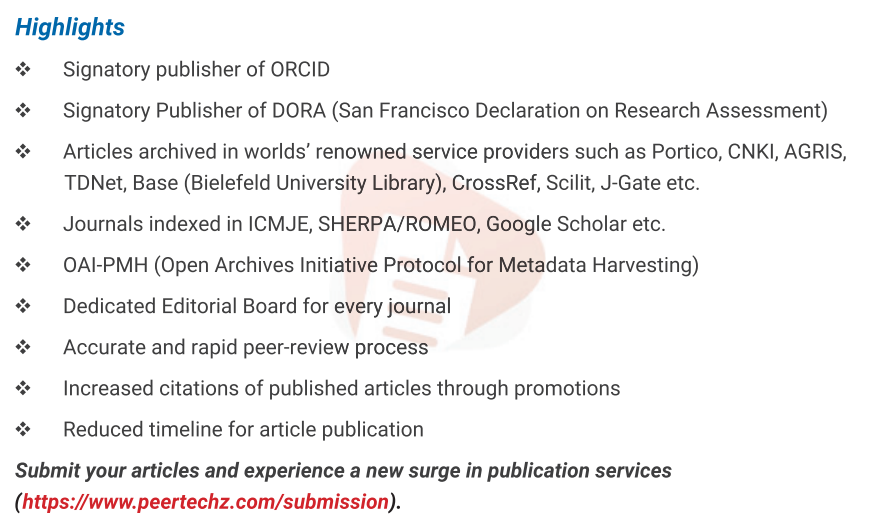

Peertechz journals wishes everlasting success in your every endeavours.

Copyright: @ 2021 Amornyotin S. This is an open-access article distributed under the terms of the Creative Commons Attribution License, which permits unrestricted use distribution, and reproduction in any medium, provided the original author and source are credited. 